\title{
The synthesis of pyrroles from $\mathrm{N}$-alkenylisoxazol-5(2H)-ones
}

\author{
Matthew Cox, Rolf H. Prager*, and Dylan M. Riessen \\ School of Chemistry, Physics and Earth Sciences, Flinders University, Adelaide 5001, \\ Australia \\ E-mail: Rolf.Prager@flinders.edu.au
}

(received 01 Jun 01; accepted 08 Aug 01; published on the web 16 Aug 01)

\begin{abstract}
Isoxazol-5(2H)-ones undergo Michael addition to propiolate esters under mildly basic conditions to form N-alkenylisoxazolones, with small amounts of the isomeric C- or O-alkylated materials. The former lose carbon dioxide when subjected to flash vacuum pyrolysis or photolysis, and give pyrroles in ca $40 \%$ yields. Minor accompanying products arise from capture of the intermediate carbene by solvent, or from hydrogen atom abstraction.
\end{abstract}

Keywords: Pyrroles, $\mathrm{N}$-alkenylisoxazol-5(2H)-ones, Michael addition, propiolate esters, flash vacuum pyrolysis, photolysis carbene

\section{Introduction}

In our study of the photochemical or thermal reactions of isoxazol-5(2H)-ones ${ }^{1}$ we have uncovered two new routes for the synthesis of pyrroles from these species. The first was an intermolecular reaction, in which the carbenoid intermediate obtained from the photolysis was reacted with an aromatic amine or an enamine (Scheme 1$)^{2}$

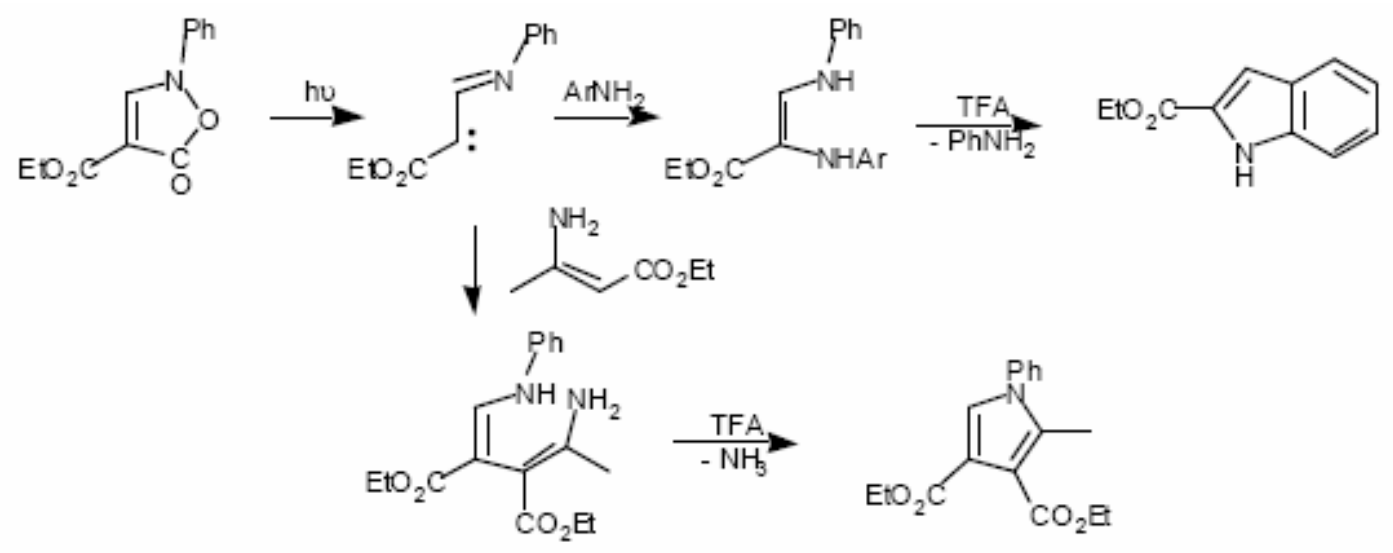

\section{Scheme 1}


While this procedure holds some promise for the synthesis of indoles, the synthesis of pyrroles by this procedure is somewhat limited. In a more recent communication ${ }^{3}$ we reported the photolysis and flash vacuum pyrolysis of two $N$-alkenylisoxazolones (Scheme 2). It appeared that photochemical reactions led to the desired pyrrole in variable yields, but that flash vacuum pyrolysis (FVP) led to a number of rearrangements. Since $N$-alkenylbenzotriazoles have been utilised by a number of workers to synthesise indoles by reactions that are formally analogous to these, ${ }^{4-7}$ in the present study we seek to extend and define the limitations of our preliminary investigation.
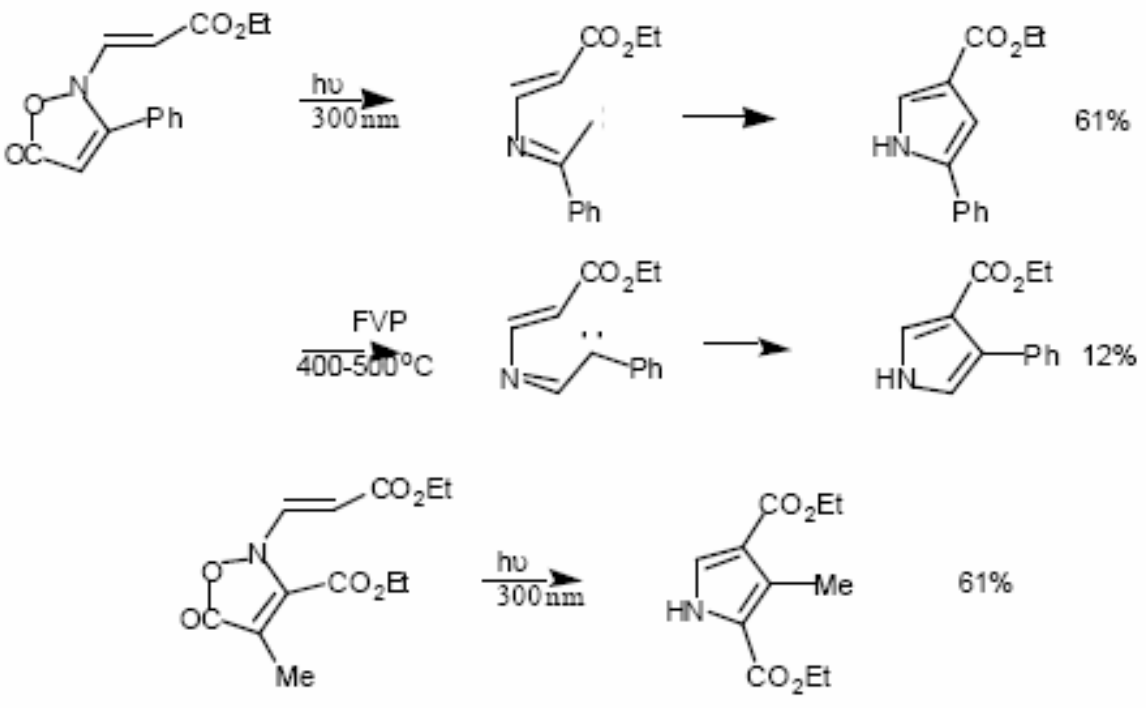

$61 \%$

Scheme 2

\section{Results and Discussion}

The accessibility of the required $N$-alkenylisoxazolone intermediates appeared the major limitation. The synthesis of the analogous $N$-alkenylbenzotriazoles ${ }^{4,8-9}$ has created considerable interest, so we examined a number of these successful approaches, but they appear to be nontransferable to the isoxazolones. Thus Rees and Storr ${ }^{8}$ showed that Nchlorobenzotriazoles could be added to alkenes, and base catalysed elimination then formed the $N$-alkenyl compound (Scheme 3).
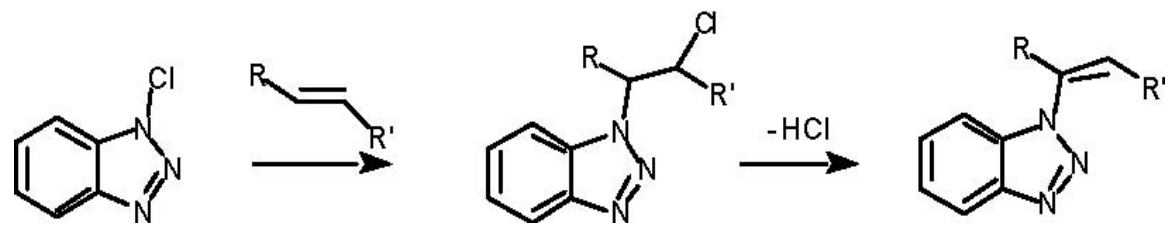

\section{Scheme 3}


Because of the sensitivity of isoxazolones towards base, ${ }^{10}$ this procedure would always be of limited application. In the event, we have found that reaction of several isoxazolones, such as $\mathbf{1}$, with NBS or t-butyl hypochlorite occurs at carbon rather than nitrogen, the assignment being based primarily on the ${ }^{13} \mathrm{C}$ nmr resonance of $\mathrm{C}-4$ in the product 2 at $49.3 \mathrm{ppm}$ (Scheme 4), confirming the earlier report of De Sarlo ${ }^{11}$ with another isoxazolone. In spite of the formation of the 4-bromo or chloro compounds, the products should be good electrophiles, and it appeared possible that addition to alkenes could still give the desired compounds through the intermediate bromonium ion 3, but in the event addition of $\mathbf{2}$ and styrene gave the C-4 adduct, 4.

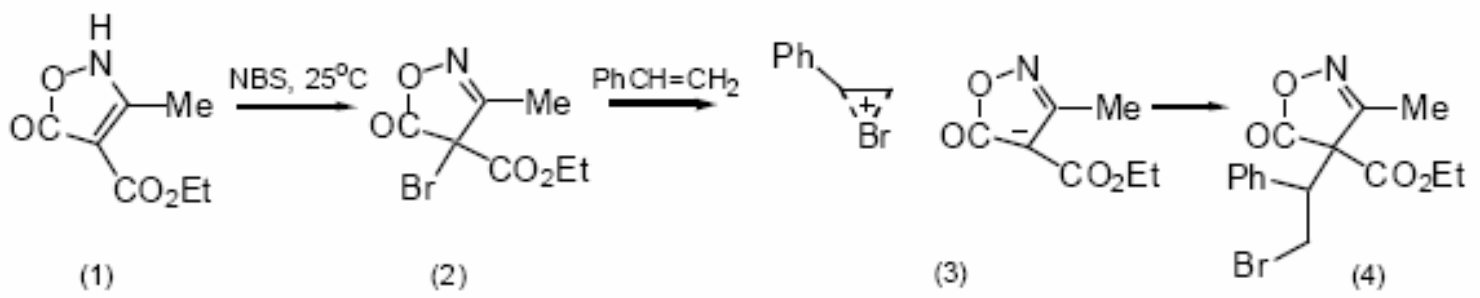

\section{Scheme 4}

An alternative approach was to react the salt of the isoxazolone with a vinyl triflate, readily prepared from the corresponding ketone. However, we have been unable to observe any such substitution; presumably the isoxazolone is insufficiently nucleophilic. ${ }^{12}$

In view of the above failure to obtain the $\mathrm{N}$-alkenylisoxazolones, we have investigated in further detail the procedure we had used previously, ${ }^{3}$ the addition of isoxazolones to propiolic esters. The necessity for base catalysis creates difficulties with 3-unsubstituted isoxazolones, as we had noted previously ${ }^{13}$ in the reaction of 4 phenylisoxazolone with ethyl propiolate: while reaction in the presence of triethylamine at room temperature in benzene gave the $\mathrm{N}$-alkenyl product, in ethanol at $80^{\circ} \mathrm{C}$ the $\mathrm{N}$-alkylated isoxazolone rearranged to the malonamide (Scheme 5).
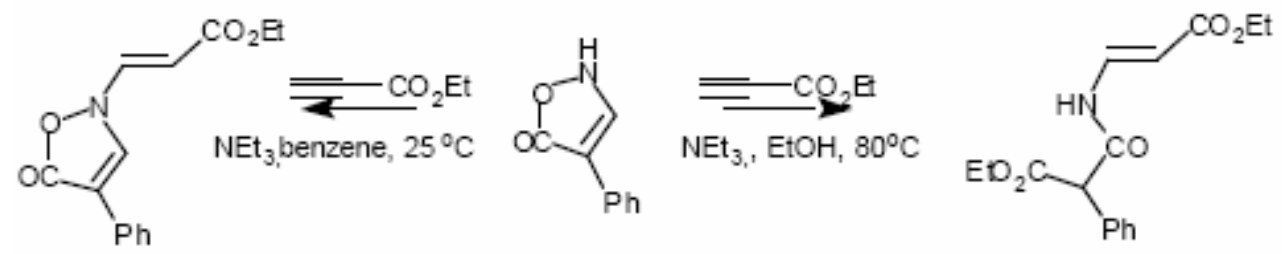

\section{Scheme 5}

The reaction of the 4-ethoxycarbonylisoxazolone $\mathbf{5}$ with ethyl propiolate in benzene in the presence of triethylamine at room temperature gave a solid whose structure was shown to be the salt 6a. Thus, although the product showed the desired vinyl doublets at $\delta 6.31$ and $7.20 \mathrm{ppm}$, the infrared absorption had dropped from $1760 \mathrm{~cm}^{-1}$ to $1718 \mathrm{~cm}^{-1}$, consistent with the anionic charge. Addition of dilute $\mathrm{HCl}$ to the salt allowed recovery of the isoxazolone 5 . When the salt was 
heated, either under FVP conditions at $540^{\circ} \mathrm{C}$, or simply sublimed at $150{ }^{\circ} \mathrm{C}$, the isoxazolone 5 was recovered, together with the Hofmann elimination product ethyl 3-diethylaminopropenoate 7a (Scheme 6). McCulloch and McInnes ${ }^{14}$ have reported that triethylamine reacts with ethyl propiolate to give the betaine $\mathbf{8}$, isolated only in low yield. This suggested to us that reaction of triethylamine with ethyl propiolate to form the acetylide is rapid, and the isoxazolone $\mathbf{5}$ functions mainly to allow rearrangement to the zwitterion $\mathbf{9}$ which is rapidly protonated. Indeed, nmr observation showed that triethylamine and ethyl propiolate react essentially instantly in $\mathrm{CDCl}_{3}$ at $28{ }^{\circ} \mathrm{C}$, presumably to form the acetylide, but the formation of 6 a requires 2-3 h for completion.
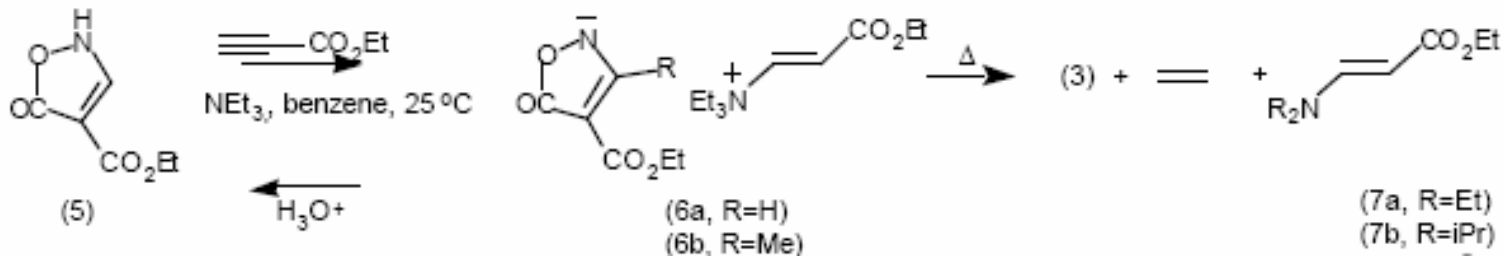

\section{Scheme 6}

Since the reaction of $\mathbf{5}$ and ethyl propiolate did not occur under neutral or acidic conditions, we examined the reaction in the presence of more hindered bases. Isoxazolone 5 was recovered unchanged after exposure to ethyl propiolate at $25{ }^{\circ} \mathrm{C}$ in the presence of diisopropylethylamine, but the formation of ethyl 3diisopropylaminopropenoate $\mathbf{7 b}$ suggested the formation of the betaine analogous to $\mathbf{6 a}$ had occurred, followed by rapid Hofmann elimination. In the presence of pyridine reaction was slow, and at $80{ }^{\circ} \mathrm{C}$ for $3 \mathrm{~h}$ the formation of a 1:2 mixture of the desired $N$ alkenyl product $\mathbf{1 0}$ and the 4-alkenyl product $\mathbf{1 1}$ was only 50\% complete: the remainder was the pyridine salt of $\mathbf{5}$. The major, C-alkylated product was a mixture of $(Z)$ and $(E)$ isomers, with the $(Z)$ diastereomer predominating. Reaction at room temperature did not proceed with either $\mathbf{1}$ or $\mathbf{5}$, yielding only the respective pyridine salt of the isoxazolone.

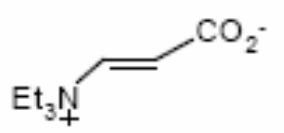

(8)

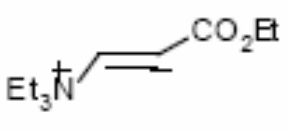

(9)

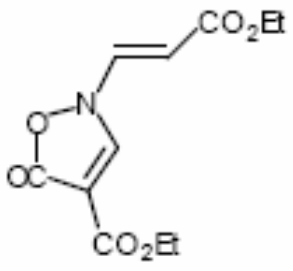

(10)

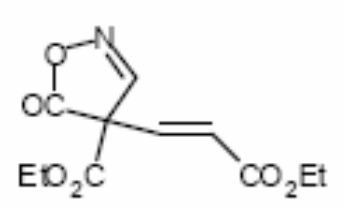

(11)

Reaction of 3-substituted isoxazolones 12a-12e with propiolate esters was less complicated, but traces of $O$-alkylated material were formed in most cases, but were readily separable by chromatography, which allowed the recovery of unreacted isoxazolone. Yields of $\mathrm{N}$-and $\mathrm{O}$ alkylated material, after chromatography, are shown in Table 1; yields of crude product were usually of the order of $75 \%$. 
Table 1. Products from the reaction of isoxazolones (12) with ethyl propiolate

\begin{tabular}{ccccc}
\hline & Isoxazolones & Propiolate & N-alkylation & O-alkylation \\
\hline & $\mathrm{R} 1$ & $\mathrm{R} 2$ & $(13)$ & $(14)$ \\
\hline 12a & $\mathrm{C}_{6} \mathrm{H}_{5}$ & $\mathrm{H}$ & 28 & 4 (ref. 3) \\
12b & $4-\mathrm{Cl} \mathrm{C}_{6} \mathrm{H}_{4}$ & $\mathrm{H}$ & 26 & 8 \\
12c & $4-\mathrm{OMe}_{6} \mathrm{H}_{4}$ & $\mathrm{H}$ & 43 & 8 \\
12d & 2-naphthyl & $\mathrm{H}$ & 29 & 9 \\
12e & $\mathrm{CH}_{3}$ & $\mathrm{H}$ & 39 & 4 \\
12e & $\mathrm{CH}_{3}$ & $\mathrm{CH}_{3}$ & 41 & 5 \\
12e & $\mathrm{CH}_{3}$ & $\mathrm{C}_{6} \mathrm{H}_{5}$ & 71 & 0 \\
\hline
\end{tabular}

The isoxazolones 13 were photolysed through pyrex in acetone, or subjected to FVP, yielding the desired pyrrole $\mathbf{1 5}$ as the major product, sometimes accompanied by the isomeric pyrrole 16, presumably formed by prior isomerisation of the carbene intermediate (Scheme 7). ${ }^{3}$ Isolated yields, after chromatography, are shown in Table 2.

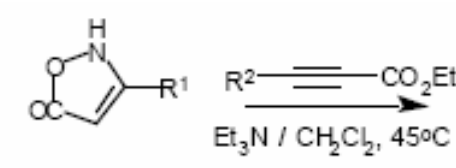

(12a, $\left.\mathrm{R}^{\prime}=\mathrm{Ph}\right)$

$\left(12 \mathrm{~b}, \mathrm{R}^{\prime \prime}=4-\mathrm{ClPh}\right)$

$\left(12 \mathrm{c}, \mathrm{R}^{\prime}=4-\mathrm{MeOPh}\right)$

(12d, R'=2-naphth)

$\left(12 \mathrm{e}, \mathrm{R}^{\prime}=\mathrm{Me}\right)$

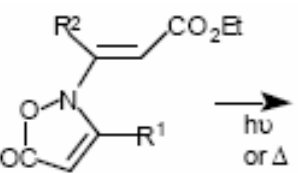

(13)

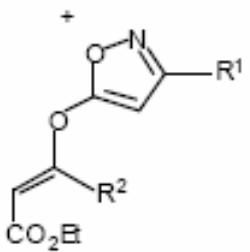

(14)<smiles>[R]c1[nH]c([R])c(C(=O)OC)c1[R]</smiles>

(15)

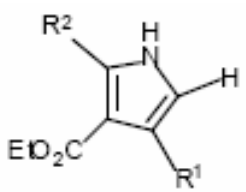

(16)

\begin{tabular}{|c|c|c|}
\hline & $\mathrm{R}^{1}$ & $\mathrm{R}^{2}$ \\
\hline (a) & $\mathrm{Ph}$ & $\mathrm{H}$ \\
\hline (b) & 4-CIPh & $\mathrm{H}$ \\
\hline (c) 4 & 4-MeOPh & $\mathrm{H}$ \\
\hline (d) 2 & 2-naphth & $\mathrm{H}$ \\
\hline (e) 1 & $\mathrm{Me}$ & $\mathrm{H}$ \\
\hline (f) $\mathrm{N}$ & Me & $\mathrm{Me}$ \\
\hline (g) 1 & $\mathrm{Me}$ & $\mathrm{Ph}$ \\
\hline
\end{tabular}

Scheme 7

Table 2. Pyrroles from isoxazolones

\begin{tabular}{lccccc}
\hline Isoxazolone & \multicolumn{5}{c}{ \% Yield of Pyrrole } \\
\cline { 2 - 6 } & hv & FVP & hv & FVP \\
\cline { 2 - 5 } & 61 & 0 & 0 & - \\
\hline $13 a$ & 21 & - & 0 & - \\
$13 b$ & 23 & - & 12 & - \\
$13 \mathrm{c}$ & 24 & - & 17 & - \\
$13 \mathrm{~d}$ & - & 66 & - & 0 \\
$13 \mathrm{e}$ & - & 93 & - & 0 \\
$13 \mathrm{f}$ & - & 19 & - & 0 \\
$13 \mathrm{~g}$ & - & & & \\
\hline
\end{tabular}


The pyrroles 15 and 16 were readily distinguishable by nmr spectroscopy, and were generally accompanied by more minor products that were informative of the reaction pathways that are open to this system. Inspection of Table 2 shows that the rearranged pyrroles $\mathbf{1 6}$ are formed predominantly with the isoxazolones $\mathbf{1 3 c}$ and 13d, suggesting that electron rich groups promote the carbene rearrangement by stabilising the intermediate $1 \mathrm{H}$-azirine (Scheme 8).

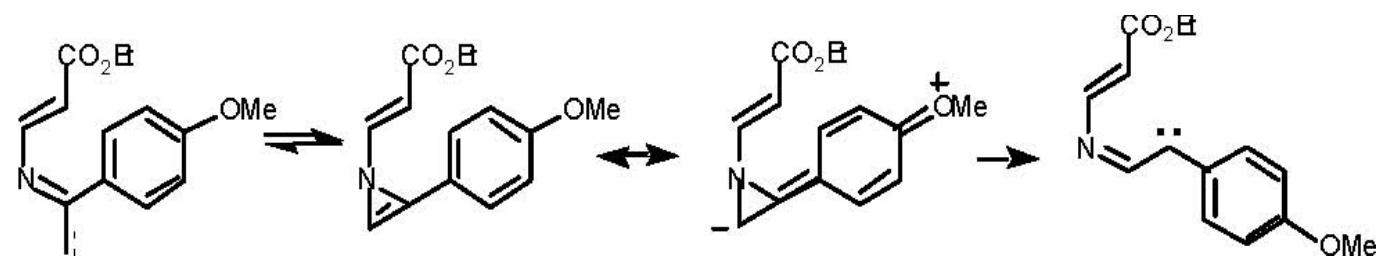

\section{Scheme 8}

The products from the FVP of the 2-naphthylisoxazolone 13d were investigated in more detail, but are typical in that isolated products total ca 70-75\%. Photolysis of 13d gave a mixture of five products, as assessed by gc/ms. The pyrroles $15 \mathbf{d}$ and $\mathbf{1 6 d}$ were isolated by chromatography, and the structures established by comparison of their spectral data. A third product was characterised as 2-acetylnaphthalene 17 (10\%), and another as an acetone addition compound, whose structure remains uncertain (19\%). The minor component (1\%) was the 4-(2naphthyl)oxazole 18. This compound is derived from the nitronoketene isomer of the isoxazolone, in an analogous process to that described previously. ${ }^{3}$ Three of the other compounds are derived from the imidoylcarbene, the 2-acetylnaphthalene arising from the triplet state by hydrogen atom abstraction from the acetone solvent, followed by hydrolysis during chromatographic purification (Scheme 9). The acetone adduct obtained from 13d is not of the same type as isolated from other compounds. For instance, photolysis of $\mathbf{1 9}$ gave the expected pyrrole 20 in only 15\% yield, but this was accompanied by $70 \%$ of the acetone adduct $\mathbf{2 1}$. The $\mathrm{sp}^{3}$ bound methyl groups in $2 \mathbf{1}$ were non equivale nt in the ${ }^{1} \mathrm{H}$ and ${ }^{13} \mathrm{C}$ nmr spectra, but the acetone adduct obtained from 13d is an adduct of the isoxazolone and acetone, having lost neither $\mathrm{CO}_{2}$ nor $\mathrm{CO}$, and with magnetically equivalent $\mathrm{C}$-Me groups.

Finally, the FVP products from $\mathbf{1 3 g}$ included the pyrrole $\mathbf{1 5 g}$ in $19 \%$ isolated yield; the major product was isomeric with it, but appears to have a pyridone structure, and will be the subject of a separate investigation. We conclude that the above synthesis of pyrroles is limited by the lack of a general procedure to form the intermediate $\mathrm{N}$-alkenyl isoxazolones. The conjugation of an ester with the double bond in these compounds clearly reduces the nucleophilicity of the double bond to the extent that what are usually minor reaction pathways of the imidoyl carbene now become significant. 


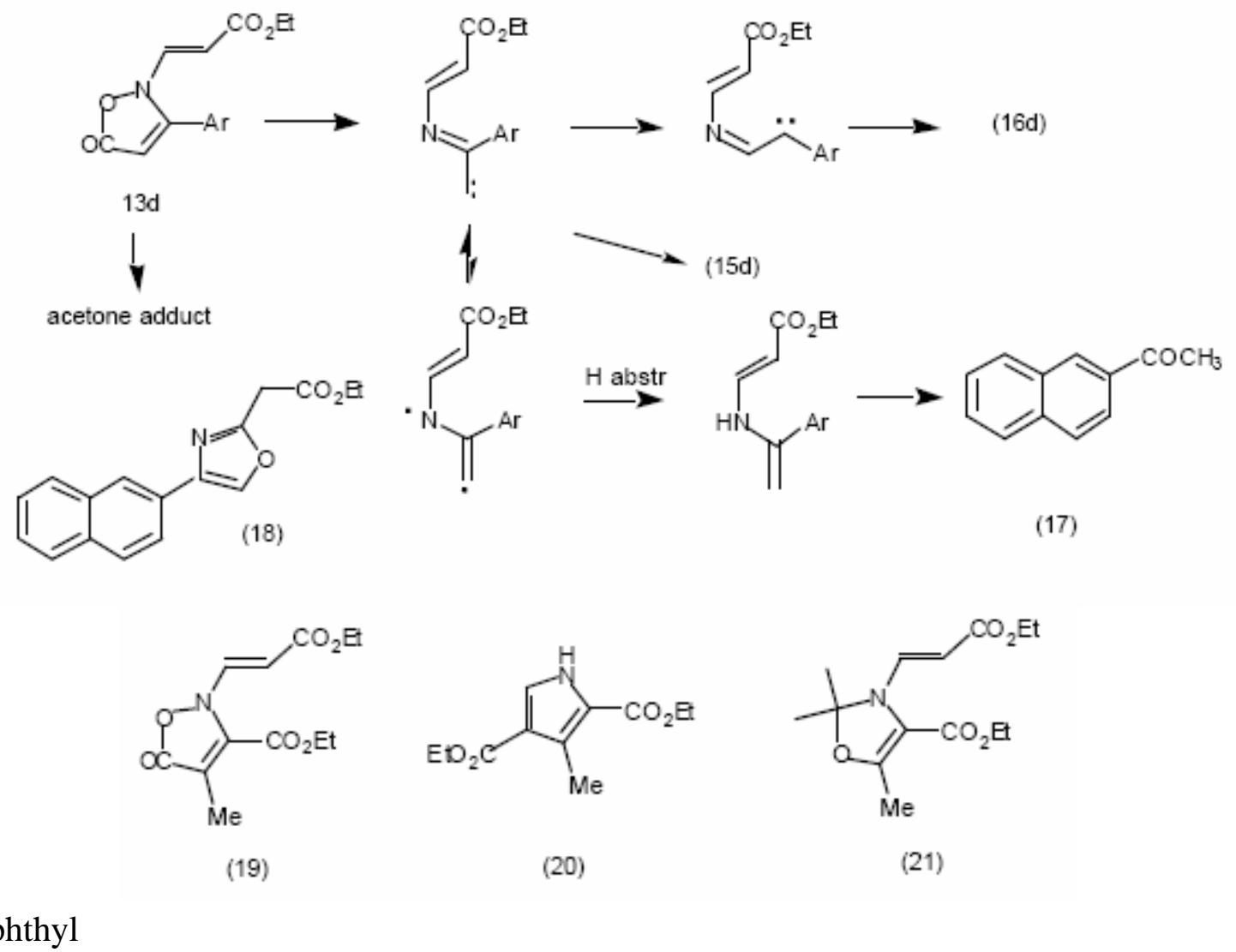

$\mathrm{Ar}=$ 2-naphthyl

\section{Scheme 9}

\section{Experimental Section}

General Procedures. NMR spectra were recorded in $\mathrm{CDCl}_{3}$ unless otherwise stated, using a Varian Mercury 200 Spectrometer operating at $200 \mathrm{MHz}$ and $50 \mathrm{MHz}$ for ${ }^{1} \mathrm{H}$ and ${ }^{13} \mathrm{C}$ respectively or a Varian Gemini 300 Spectrometer operating at $300 \mathrm{MHz}$ and $75.5 \mathrm{MHz}$. Infrared spectra were recorded on a Perkin Elmer 1600 FT-IR spectrophotometer using fused sodium chloride cells as nujol mulls for solids and as films for liquids. Mass spectra and accurate mass determination were recorded on a Kratos MS25RF spectrometer. GC/MS analyses were performed on a Varian Saturn 4D GC/MS using a J \& W DB5 5\% phenyl methyl polysiloxane column (30m, $0.25 \mathrm{~mm}$ ID, $0.25 \mathrm{~mm}$ thickness). Centrifugal chromatography was performed using a Chromatotron (model 7924T) with silica gel 60 PF254. All column chromatography was performed using Reidel-de Haen Silica gel S. Merck silica gel 60 F254 aluminium backed sheets were used for analytical thin layer chromatography. All melting points are uncorrected. Photolyses were performed at 300nm using a low-pressure mercury lamp, filtered by using pyrex glassware. 
Ethyl 4-bromo-3-methyl-5-oxo-2,5-dihydroisoxazole-4-carboxylate (2). Ethyl 3-methyl-5oxo-2,5-dihydroisoxazole-4-carboxylate 1 (750 mg; $4.4 \mathrm{mmo} \mathrm{l}$ ) was stirred with a suspension of $\mathrm{N}$-bromosuccinimide (780 mg; $4.4 \mathrm{mmol}$ ) in carbon tetrachloride (30 mL) for $40 \mathrm{~min}$ at rt. The succinimide was removed and the filtrate was washed with water, dried and evaporated to give the title compound as clear yellow oil (0.97 g; 88 \%). ${ }^{1} \mathrm{H}$ NMR. $\delta$ : 4.34, q $J 6.5 \mathrm{~Hz}, 2 \mathrm{H}$; 2.23, s, $3 \mathrm{H}$; 1.31, t, $J 6.6 \mathrm{~Hz}, 3 \mathrm{H} .{ }^{13} \mathrm{C}$ NMR $\delta$ : 169.7, 162.6, 160.0, 65.3, 49.3, 13.7, 12.3. The compound did not give a molecular ion.

Ethyl 4-chloro-3-methyl-5-oxo-2,5-dihydroisoxazole-4-carboxylate. A solution of $t$-butyl hypochloride (190 mg; $1.8 \mathrm{mmol})$ in benzene $(10 \mathrm{~mL})$ was added dropwise over 10 minutes to a suspension of 1 (300 mg; $1.8 \mathrm{mmol}$ ) in benzene (10 mL) at 0 C. After 40 min the solution was evaporated to give the crude title compound (165 mg; 56\%). ${ }^{1} \mathrm{H}$ NMR $\delta: 4.13, \mathrm{q}, \mathrm{J} 7 \mathrm{~Hz}, 2 \mathrm{H}$; 2.28, s, 3H; 1.17, t, $J$ 7Hz, 3H. ${ }^{13} \mathrm{C}$ NMR. $\delta: 168.7 ; 162.8 ; 161.9 ; 65.1 ; 59.5 ; 13.5 ; 11.5$. The compound did not give a molecular ion.

Attempted synthesis of ethyl 4-(2-bromo-1-phenylethyl)-3-methyl-5-oxo-2,5-dihydroisoxazole-4-carboxylate (4). A mixture of isoxazolone 1 (300 mg), Nbromosuccinimide (312 $\mathrm{mg}$ ) and styrene (187 mg) was stirred for $16 \mathrm{~h}$ in carbon tetrachloride or dichloromethane (15 $\mathrm{mL}$ ). The mixture was filtered and the solvent evaporated to give oil, which contained ca $25 \%$ of the title compound as well as starting material. ${ }^{1} \mathrm{H}$ NMR for $4 \delta: 4.25$, d, $J=7 \mathrm{~Hz}, 2 \mathrm{H} ; 3.85$, m, $1 \mathrm{H}$;. 3.62, dd , $J 10 \mathrm{~Hz}, 3 \mathrm{~Hz}, 1 \mathrm{H}$; 3.55, dd, $J 10 \mathrm{~Hz}, 9 \mathrm{~Hz}, 1 \mathrm{H} ; 2.20$, s, 3H; 1.31, t, $J$ 7Hz, $3 \mathrm{H}$. ${ }^{13} \mathrm{C}$ NMR $\delta$ : 170.2; 160.1; 153.9; 129.5; 126.4; 65.3; 60.5; 47.4; 41.2; 14.4; 12.2. When reaction was extended to $4 \mathrm{~d}$ at rt, $\mathrm{nmr}$ analysis indicated that the reaction was still only $50 \%$ complete.

No reaction occurred with cyclohexene under similar conditions.

\section{2-Ethoxycarbonylethenyltriethylammonium 4-ethoxycarbonylisoxazole-5-oxide (6a)}

(i) Triethylamine (370 mg; $3.66 \mathrm{mmol}$ ) was added to a stirred suspension of ethyl 5-oxo-2,5dihydroisoxazole-4-carboxylate 5 (505 mg; $3.21 \mathrm{mmol}$ ) and ethyl propiolate (347 mg; 3.57 mmol) in benzene $(15 \mathrm{~mL})$. The solution was stirred for $16 \mathrm{~h}$ at room temperature after which time the solvent was evaporated leaving $6 \mathbf{6}$ as a white solid (1.12 g; 95\%), mp. 128 C dec. ${ }^{1} \mathrm{H}$ NMR $\delta$ : 8.18, s, 1H; 7.20, d, $J 9.6 \mathrm{~Hz}, 1 \mathrm{H} ; 6.31$, d, $J 9.6 \mathrm{~Hz}, 1 \mathrm{H}$; 4.25, q, $J$ 7.2 Hz, 2H; 4.13, q, $J$ 7.2Hz, 2H; 3.79, q, $J 7.2 \mathrm{~Hz}, 6 \mathrm{H} ; 1.37$, t, $J 7.2 \mathrm{~Hz}, 9 \mathrm{H}$; 1.29 , t, $J$ 7.2 Hz, $6 \mathrm{H} .{ }^{13} \mathrm{C}$ NMR $\delta: 176.7$; 165.0; 162.8; 153.8; 145.3; 123.4; 80.2; 62.3; 58.1; 55.3; 14.8; 13.9; 8.0. $v_{\max }: 1718,1636 \mathrm{~cm}^{-1}$.

An analogous product $\mathbf{6 b}$ was obtained in $>90 \%$ yield when $\mathbf{1}$ was reacted as above. ${ }^{1} \mathrm{H}$ NMR $\delta: ~ 7.18$, d, $J 14 \mathrm{~Hz}, 1 \mathrm{H}$; 6.36, d, $J 14 \mathrm{~Hz}, 1 \mathrm{H} ; 4.19$, q, $J 7.2 \mathrm{~Hz}, 2 \mathrm{H} ; 4.10$, q, $J$ 7.2Hz, 2H; 4.10, q, $J$ 7.2Hz, 2H; 3.72, q, $J 7.2 \mathrm{~Hz}, 6 \mathrm{H} ; 2.18$, s, 3H; 1.2-1.35, m, 15H. ${ }^{13} \mathrm{C}$ NMR $\delta: 165.0 ; 162.5$; 145.3; 133.5; 123.4; 118.6; 98.7; 62.4; 58.0; 55.4; 14.8; 14.5; 13.9;8.1.

(ii) Isoxazolone 5 (51 mg; $0.32 \mathrm{mmol}$ ), ethyl propiolate (84 mg; $0.86 \mathrm{mmol}$ ) and triethylamine (61 mg; $0.60 \mathrm{mmol}$ ) were dissolved in an NMR tube in deuterated chloroform and analysed at $15 \mathrm{~min}$ intervals over $3 \mathrm{~h}$. This revealed that the reaction of the triethylamine with the ethyl propiolate was almost instantaneous, with the isoxazolone forming its respective anion much more slowly.

Pyrolysis of 6a. (i) Compound 6a (220 mg; $0.62 \mathrm{mmol}$ ) was sublimed at $150 \mathrm{C}$ and passed 
through the pyrolysis column at 540 C. Gc/ms analysis revealed the presence of four products. The most volatile was confirmed to be ethyl cyanoacetate (20\%) by direct comparison. The second product (10\%) is believed to be ethyl 3-ethylaminopropenoate from examination of its mass spectrum. The third product was compound 7a, (50\%), and the fourth (10\%) is unidentified.

(ii) Sublimation of $\mathbf{6 a}$ at $150{ }^{\circ} \mathrm{C} / 0.03 \mathrm{~mm}$ gave an oil, the major component of which was identified as ethyl (E)-3-diethylaminopropenoate $\mathbf{7 a}$.

(iii) Compound 6a (475 mg; $1.3 \mathrm{mmol}$ ) was dissolved in xylene and the solution refluxed for 30 min. The solvent was evaporated to give a clean sample of ethyl (E)-3diethylaminopropenoate 7a. (Found: $\mathrm{M}^{+}, 171.1264 . \mathrm{C}_{9} \mathrm{H}_{17} \mathrm{NO}_{2}$ requires $\mathrm{M}^{+}, 171.1259$ ). ${ }^{1} \mathrm{H}$ NMR $\delta: ~ 7.42$, d, $J 12 \mathrm{~Hz}, 1 \mathrm{H}$; 4.55, d, $J 12 \mathrm{~Hz}, 1 \mathrm{H} ; 4.11$, q, $J$ 7Hz, 2H; 3.16, q, $J$ 7Hz, 4H; 1.24 , t, $J$ $\mathrm{Hz}, 3 \mathrm{H} ; 1.13$, t $, J 7 \mathrm{~Hz}, 6 \mathrm{H} .{ }^{13} \mathrm{C}$ NMR. $\delta$ : 170.0; 150.8; 83.2; 63.6; 58.7; 14.6; 13.9. Mass spectrum m/z: 171 (M+, 45), 156 (15), 142 (81), 126 (100), 98 (54), 86 (66).

Ethyl (E)-3-diisopropylaminopropenoate (7b). Di-isopropylethylamine (250 mg; $1.9 \mathrm{mmol}$ ) was added to a stirred suspension of ethyl 5-oxo-2,5-dihydroisoxazole-4-carboxylate 5 (300 mg; $1.9 \mathrm{mmol})$ and ethyl propiolate (200 $\mathrm{mg} ; 2.0 \mathrm{mmol})$ in ethanol $(15 \mathrm{~mL})$. The solution was refluxed for $3 \mathrm{~h}$ and the solvent was evaporated. The major product was ethyl (E)-3-diisopropylaminopropenoate $7 \mathbf{b}$. (Found: $\mathrm{M}^{+}, 199.1580 . \mathrm{C}_{11} \mathrm{H}_{21} \mathrm{NO}_{2}$ requires $\mathrm{M}^{+}$, 199.1572). ${ }^{1} \mathrm{H}$ NMR $\delta: 7.50$, d, $J 10 \mathrm{~Hz}, 1 \mathrm{H} ; 4.55$, d, $J 10 \mathrm{~Hz}, 1 \mathrm{H} ; 4.13$, q, $J 6 \mathrm{~Hz}, 2 \mathrm{H} ; 3.70$, sep, $J 6.5 \mathrm{~Hz}, 2 \mathrm{H}$; 1.41, d, $J 6.5 \mathrm{~Hz}, 6 \mathrm{H} ; 1.25$, t, $J 6 \mathrm{~Hz}, 3 \mathrm{H} .{ }^{13} \mathrm{C}$ NMR $\delta$ : 164.7; 153.5; 83.2; 63.6; 58.4; 18.7; 14.6.

Attempted synthesis of ethyl 2-(2-ethoxycarbonylethenyl)-5-oxo-2,5-dihydroisoxazole-4carboxylate (10). Pyridine (5 drops) was added to a stirred suspension of 5 (300 mg; $1.9 \mathrm{mmol}$ ) and ethyl propiolate (200 mg; $2.0 \mathrm{mmol}$ ) in ethanol (15 mL). The solution was refluxed for $3 \mathrm{~h}$ and the solvent was evaporated. The residue was taken up in ether $(50 \mathrm{~mL})$ and washed with $2 \mathrm{M}$ $\mathrm{HCl}(2 \times 20 \mathrm{~mL})$. The ethereal layer was evaporated. NMR analysis showed the product to consist of a mixture of $\mathbf{1 0}$ and $\mathbf{1 1}$ in the ratio of 2:1 (55\%), ethyl cyanoacetate (15\%), and the pyridine salt of 5 (30\%). Diagnostic ${ }^{1} \mathrm{H}$ NMR 10, $\delta$ : (Z) isomer 6.46, d, J $10 \mathrm{~Hz}$; 7.90, d, J 10 $\mathrm{Hz}$; (E) isomer, 5.95, d, $J 16 \mathrm{~Hz}$; 7.60, d, $J 16 \mathrm{~Hz}$; Diagnostic ${ }^{1} \mathrm{H}$ NMR 11, $\delta:(Z)$ isomer 5.41, d, $J 11 \mathrm{~Hz}$; 6.76, d, $J 11 \mathrm{~Hz}$ ); (E) isomer 6.62, d, $J 14 \mathrm{~Hz}$; 7.05, d, $J 14 \mathrm{~Hz}$.

No product formation was observed in the absence of base in $\mathrm{CH}_{2} \mathrm{Cl}_{2}\left(16 \mathrm{~h}, 40{ }^{\circ} \mathrm{C}\right)$, or benzene with 2 equiv. $\mathrm{CF}_{3} \mathrm{CO}_{2} \mathrm{H}\left(6 \mathrm{~h}, 50{ }^{\circ} \mathrm{C}\right)$. In toluene (16 h, $\left.110{ }^{\circ} \mathrm{C}\right)$, NMR analysis indicated the presence of (E)-10, (7\%), and (Z)-11, (10\%); the major product (80\%) was ethyl cyanoacetate.

Reaction of 3-(4-chlorophenyl)isoxazol-5(4H)-one with ethyl propiolate. 3-(4Chlorophenyl)isoxazol-5(4H)-one ${ }^{15} \mathbf{1 2 b}(0.25 \mathrm{~g}, 1.3 \mathrm{mmol})$, ethyl propiolate $(0.125 \mathrm{~g}, 1.3 \mathrm{mmol})$ and triethylamine $(0.129 \mathrm{~g}, 1.3 \mathrm{mmol})$ were refluxed in dichloromethane $(10 \mathrm{~mL})$ for $6 \mathrm{~h}$. The solvent was evaporated and the residue was redissolved in ether $(30 \mathrm{~mL})$ and then washed with $1 \mathrm{M} \mathrm{HCl}(2 \mathrm{x} 20 \mathrm{~mL})$. The organic layer was separated, dried $\left(\mathrm{Na}_{2} \mathrm{SO}_{4}\right)$, filtered and evaporated to give clear yellow oil $(0.262 \mathrm{~g}, 70 \%)$, which was purified by radial chromatography ( $10 \%$ ethyl acetate/light petroleum) to give three fractions. The first fraction contained 3-(4-chlorophenyl)-5- 
(2-ethoxycarbonylethenyloxy)isoxazole 14 b as a white solid $\left(0.029\right.$ g, 8\%), m.p. $78-80{ }^{\circ} \mathrm{C}$ (Found: $\mathrm{M}^{+}$, 293.0456. $\mathrm{C}_{14} \mathrm{H}_{12} \mathrm{NO}_{4} \mathrm{Cl}$ requires $\mathrm{M}^{+}$, 293.0455). ${ }^{1} \mathrm{H} \mathrm{NMR} . \delta$ 7.82, d, $J 11.9 \mathrm{~Hz}, 1 \mathrm{H}$; 7.69, d, J 8.4 Hz, 2H; 7.43, d, J 8.4 Hz, 2H; 5.90, d, J 12 Hz, 1H; 5.86, s, $1 \mathrm{H}$; 4.24, q, J 7.1 Hz, $2 \mathrm{H}$; 1.31, t, $J$ 7.1 Hz, 3H. ${ }^{13} \mathrm{C}$ NMR $\delta$ 169.9, 165.7, 163.7, 153.9, 136.9, 129.5, 128.0, 127.4, 107.4, 80.1, 61.0, 14.4. Umax 1709, 1622, $1464 \mathrm{~cm}^{-1}$. Mass spectrum (m/z) $293\left(\mathrm{M}^{+}, 2.5 \%\right), 224$ (10), 196 (20), 179 (84), 150.5 (72), 139 (100), 123 (34), 111 (28), 75 (32), 50 (25).

The second fraction contained ethyl $(E)$ - 3-\{3-(4-chlorophenyl)-5-oxo-2,5-dihydroisoxazol2-yl propenoate $\mathbf{1 3 b}$ as a pale yellow powder $\left(0.088 \mathrm{~g}, 23 \%\right.$ ), mp. $108-110{ }^{\circ} \mathrm{C}$. (Found: $\mathrm{M}^{+}$, 293.0455. $\mathrm{C}_{14} \mathrm{H}_{12} \mathrm{NO}_{4} \mathrm{Cl}$ requires $\mathrm{M}^{+}$, 293.0455). ${ }^{1} \mathrm{H} \mathrm{NMR} \delta$ 7.41-7.58, m, 5H; 5.88, d, $J=13.4$ $\mathrm{Hz}, 1 \mathrm{H} ; 5.49$, s, $1 \mathrm{H} ; 4.17, \mathrm{q}, J=7.0 \mathrm{~Hz}, 2 \mathrm{H} ; 1.26$, t, $J=7.0 \mathrm{~Hz}$, 3H. ${ }^{13} \mathrm{C}$ NMR $\delta 166.7,166.5$, 159.6, 139.0, 132.9, 130.4, 129.9, 123.8, 102.9, 91.8, 60.9, 14.4. U $\max 1774,1709,1635,1608$, 1579, 1559, $1488 \mathrm{~cm}^{-1}$. Mass spectrum (m/z) $293\left(\mathrm{M}^{+}, 70 \%\right), 248$ (60), 221 (27), 220 (22), 180 (62), 178 (100), 150 (87), 136 (97), 101 (38), 84 (54), 75 (57), 44 (87). The third fraction contained ethyl (Z)-3-(3-(4-chlorophenyl)-5-oxo-2,5-dihydroisoxazol-2-yl) propenoate 13b as a pale yellow solid (0.012 g, 3\%), mp. 120-122 ${ }^{\circ} \mathrm{C}$ (Found: $\mathrm{M}^{+}$, 293.0454. $\mathrm{C}_{14} \mathrm{H}_{12} \mathrm{NO}_{4} \mathrm{Cl}$ requires $\mathrm{M}^{+}$, 293.0455). ${ }^{1} \mathrm{H}$ NMR $\delta$ 7.4-7.56, m, 4H; 6.43, d, $J=9.7 \mathrm{~Hz}, 1 \mathrm{H} ; 5.47, \mathrm{~s}, 1 \mathrm{H} ; 5.35$, d, $J=9.7$ $\mathrm{Hz}, 1 \mathrm{H} ; 4.29$, q, $J=7.1 \mathrm{~Hz}, 2 \mathrm{H} ; 1.35$, t, $J=7.1 \mathrm{~Hz}, 3 \mathrm{H} .{ }^{13} \mathrm{C}$ NMR $\delta 167.4,164.3,160.7,138.6$, 129.9, 129.7, 126.8, 124.4, 105.8, 90.6, 61.2, 14.0 . $v_{\max } 1751,1732,1647,1487 \mathrm{~cm}^{-1}$. Mass spectrum (m/z) 293 (M+, 25\%), 248 (29), 221 (14), 203 (10), 163 (16), 136 (61), 101 (26), 84 (44), 44 (100).

Photolysis of $\mathbf{1 3 b}$. The $(E)$ isomer $\mathbf{1 3 b}(0.08 \mathrm{~g}, 0.27 \mathrm{mmol})$ was photolysed through pyrex at 300 $\mathrm{nm}$ in anhydrous acetone $(150 \mathrm{~mL})$ under $\mathrm{N}_{2}$ at room temperature for $3 \mathrm{~h}$. The solvent was evaporated and the residue was purified by radial chromatography (10\% ethyl acetate/light petroleum) to give two main fractions.

The first fraction contained 4-chloroacetophenone (0.005 g, 10\%), isolated as a colourless oil, the structure of which was confirmed by comparison with an authentic sample. ${ }^{1} \mathrm{H}$ NMR $\delta$ 7.89, d, $J=8.3 \mathrm{~Hz}, 2 \mathrm{H}$; 7.43, d, $J=8.3 \mathrm{~Hz}, 2 \mathrm{H}$; 2.61, s, 3H. ${ }^{13} \mathrm{C}$ NMR $\delta 197.3,137.2,131.22$, 129.3, 128.7, 27.4 .

The second fraction contained ethyl 5-(4-chlorophenyl)pyrrole-3-carboxylate 15b, isolated as a white powder (0.014g, 21\%), m.p. 130-132 ${ }^{\circ} \mathrm{C}$. (Found: $\mathrm{M}^{+}, 249.0557 . \mathrm{C}_{13} \mathrm{H}_{12} \mathrm{NO}_{2} \mathrm{Cl}$ requires $\mathrm{M}^{+}$, 249.0557). ${ }^{1} \mathrm{H}$ NMR $\delta$ 9.49, bs, $1 \mathrm{H}, \mathrm{NH} ; 7.51$, d, $J=8.8 \mathrm{~Hz}, 2 \mathrm{H} ; 7.37, \mathrm{~d}, J=8.8 \mathrm{~Hz}, 2 \mathrm{H}$; 6.95, dd, $J=2.4,4.0 \mathrm{~Hz}, 1 \mathrm{H} ; 6.51$, dd, $J=2.4$, $4.0 \mathrm{~Hz}, 1 \mathrm{H} ; 4.34$, q, $J=7.1 \mathrm{~Hz}, 2 \mathrm{H} ; 1.37$, t, $J=$ $7.1 \mathrm{~Hz}, 3 \mathrm{H} .{ }^{13} \mathrm{C}$ NMR $\delta 161.3,135.5,133.5,129.9,129.2,125.9,123.8,116.7,108.3,60.5,14.5$. $v_{\max } 1686 \mathrm{~cm}^{-1}$. Mass spectrum (m/z) $249\left(\mathrm{M}^{+}, 72\right), 204$ (100), 175 (19), 149 (23), 140 (46), 111 (7), 75 (8), 43 (14).

Reaction of 3-(4-methoxyphenyl)isoxazol-5(4H)-one with ethyl propiolate. 3-(4Methoxyphenyl)isoxazol-5(4H)-one ${ }^{15}$ 12c $(0.26 \mathrm{~g}, 1.36 \mathrm{mmol})$, ethyl propiolate $(0.133 \mathrm{~g}, 1.36$ mmol) and triethylamine $(0.137 \mathrm{~g}, 1.36 \mathrm{mmol})$ were reacted as above. The product $(0.303 \mathrm{~g}$, $)$ was purified by radial chromatography (10\% ethyl acetate/light petroleum), to give three main fractions. 
The first fraction contained 5-(2-ethoxycarbonylethenyloxy) 3-(4-methoxyphenyl)isoxazole 14c as a clear oil (0.03 g, 8\%). (Found: $\mathrm{M}^{+}$, 289.0952. $\mathrm{C}_{15} \mathrm{H}_{15} \mathrm{NO}_{5}$ requires $\mathrm{M}^{+}$, 289.0950). ${ }^{1} \mathrm{H}$ NMR $\delta$ 8.06, d, $J=12.6 \mathrm{~Hz}, 1 \mathrm{H} ; 7.66, \mathrm{~d}, J=8.6 \mathrm{~Hz}, 2 \mathrm{H} ; 7.26, \mathrm{~s}, 1 \mathrm{H} ; 6.91, \mathrm{~d}, J=8.6 \mathrm{~Hz}, 2 \mathrm{H}$; 5.66, d, $J=12.6 \mathrm{~Hz}, 1 \mathrm{H} ; 4.19$, q, $J=7.1 \mathrm{~Hz}, 2 \mathrm{H}$; 3.84, s, 3H; 1.29 , t, $J=7.1 \mathrm{~Hz}, 3 \mathrm{H} .{ }^{13} \mathrm{C}$ NMR $\delta$ 169.3, 165.4, 162.8, 155.3, 134.2, 129.7, 114.3, 113.5, 112.9, 84.4, 61.3, 56.1, 14.4.

The second fraction contained ethyl (E)-3-\{3-(4-methoxyphenyl)-5-oxo-2,5-dihydroisoxazol2-yl $\}$ propenoate $13 \mathrm{c}$ as a fine yellow powder $\left(0.139\right.$ g, 35\%), m.p. $122^{\circ} \mathrm{C}$. (Found: $\mathrm{M}^{+}, 289.0954$. $\mathrm{C}_{15} \mathrm{H}_{15} \mathrm{NO}_{5}$ requires $\mathrm{M}^{+}$, 289.0950). ${ }^{1} \mathrm{H}$ NMR $\delta 7.58$, d, $J=13.2 \mathrm{~Hz}, 1 \mathrm{H} ; 7.42$, d, $J=8.6 \mathrm{~Hz}, 2 \mathrm{H}$; 7.04, d, $J=8.6 \mathrm{~Hz}, 2 \mathrm{H} ; 5.86$, d, $J=13.2 \mathrm{~Hz}, 1 \mathrm{H} ; 5.42$, s, $1 \mathrm{H} ; 4.16, \mathrm{q}, J=7.1 \mathrm{~Hz}, 2 \mathrm{H} ; 3.88$, s, $3 \mathrm{H} ; 1.25$, t $J=7.1 \mathrm{~Hz}, 3 \mathrm{H} .{ }^{13} \mathrm{C}$ NMR $\delta 166.5,162.6,160.6,133.4,130.1,129.9,117.1,115.1$, 101.9, 90.4 , 60.5, 55.5, 14.1. $v_{\max } 1770,1709,1633,1611,1507,1442 \mathrm{~cm}^{-1}$. Mass spectrum (m/z) 289 (M+1 15\%), 234 (13), 204 (6), 159 (9), 151 (31), 135 (100), 92 (14), 84 (50).

The third fraction contained the $(\mathrm{Z})$ isomer of $\mathbf{1 3 c}$, isolated as white needles $(0.032 \mathrm{~g}, 8 \%)$, mp. 53-54 ${ }^{\circ} \mathrm{C}$. (Found: $\mathrm{M}^{+}$, 289.0952. $\mathrm{C}_{15} \mathrm{H}_{15} \mathrm{NO}_{5}$ requires $\mathrm{M}^{+}$, 289.0950). ${ }^{1} \mathrm{H}$ NMR $\delta 7.81, \mathrm{~d}, J=$ $12.1 \mathrm{~Hz}, 1 \mathrm{H}$; 7.68, d, $J=8.6 \mathrm{~Hz}, 2 \mathrm{H} ; 6.96$, d, $J=8.6 \mathrm{~Hz}, 2 \mathrm{H} ; 5.88$, d, $J=12.1 \mathrm{~Hz}, 1 \mathrm{H} ; 5.83$, s, $1 \mathrm{H}$; 4.23, q, $J=7.1 \mathrm{~Hz}, 2 \mathrm{H}$; 3.84, s, 3H; 1.31 , t, $J=7.1 \mathrm{~Hz}, 3 \mathrm{H} .{ }^{13} \mathrm{C}$ NMR $\delta 169.3,164.1,161.3$, $153.6,127.9,127.8,114.3,114.1,106.8,79.6,60.7,55.3,14.2$. $v_{\max } 1750,1714,1666,1605$, 1574, $1531 \mathrm{~cm}^{-1}$. Mass spectrum (m/z) $289\left(\mathrm{M}^{+}, 2.5 \%\right), 150$ (19), 135 (100), 92 (14), 77 (21), 43 (7).

Photolysis of 13c. The $(E)$ isomer of 13c $(0.103 \mathrm{~g}, 0.36 \mathrm{mmol})$ was photolysed through pyrex at $300 \mathrm{~nm}$ in anhydrous acetone $(150 \mathrm{~mL})$ under $\mathrm{N}_{2}$ at room temperature for 3h. Purification by radial chromatography (10\% ethyl acetate/light petroleum) gave three fractions.

The first fraction contained 4-methoxyacetophenone as a pale yellow oil $(0.016 \mathrm{~g}, 30 \%)$, the identity of which was confirmed by direct comparison with an authentic sample.

The second fraction contained ethyl 5-(4-methoxyphenyl)pyrrole-3-carboxylate $\mathbf{1 5 c}$ as a white solid (0.02 g, 23\%), mp. $123{ }^{\circ} \mathrm{C}$. (Found: $\mathrm{M}^{+}$, 245.1051. $\mathrm{C}_{14} \mathrm{H}_{15} \mathrm{NO}_{3}$ requires $\mathrm{M}^{+}$, 245.1052). ${ }^{1} \mathrm{H}$ NMR $\delta$ 9.45, bs, $1 \mathrm{H}, \mathrm{NH} ; 7.50$, d, $J=8.9 \mathrm{~Hz}, 2 \mathrm{H}$; 6.96, d, $J=8.9 \mathrm{~Hz}, 2 \mathrm{H} ; 6.95$, dd , $J=2.7,3.9 \mathrm{~Hz}, 1 \mathrm{H} ; 6.43$, dd, $J=2.7,3.9 \mathrm{~Hz}, 1 \mathrm{H} ; 4.33$, q, $J=7.1 \mathrm{~Hz}, 2 \mathrm{H} ; 3.83$, s, 3H; 1.37, t, $J=7.1 \mathrm{~Hz}, 3 \mathrm{H} .{ }^{13} \mathrm{C}$ NMR $\delta 161.3,136.9,131.8,126.1,124.3,116.8,114.4,107.0,90.5,60.3$, 55.3, 14.5. $v_{\max } 1681,1468 \mathrm{~cm}^{-1}$. Mass spectrum (m/z) $245\left(\mathrm{M}^{+}, 50\right), 199$ (66), 171 (22), 145 (17), 135 (100), 128 (12), 92 (13), 77 (24), 43 (59).

The third fraction contained ethyl 4-(4-methoxyphenyl)pyrrole-3-carboxylate 16c which was isolated as a pale yellow solid (0.01 g, 12\%), mp. 62-64 ${ }^{\circ} \mathrm{C}$ (Found: $\mathrm{M}^{+}$, 245.1055. $\mathrm{C}_{14} \mathrm{H}_{15} \mathrm{NO}_{3}$ requires $\mathrm{M}^{+}$, 245.1052). ${ }^{1} \mathrm{H}$ NMR $\delta 8.77$, bs, $1 \mathrm{H}, \mathrm{NH} ; 7.44$, dd , $J=1.6,3.2 \mathrm{~Hz}, 1 \mathrm{H} ; 7.40$, d, $J=$ $8.9 \mathrm{~Hz}, 2 \mathrm{H}$; 6.92, d, $J=8.9 \mathrm{~Hz}, 2 \mathrm{H} ; 6.79$, dd, $J=1.6,3.2 \mathrm{~Hz}, 1 \mathrm{H} ; 4.3, \mathrm{q}, J=7.1 \mathrm{~Hz}, 2 \mathrm{H} ; 3.83$, s, $3 \mathrm{H} ; 1.35$, t, $J=7.1 \mathrm{~Hz}, 3 \mathrm{H} .{ }^{13} \mathrm{C}$ NMR $\delta 165.2,130.1,125.8,123.7,114.7,113.8,109.9,105.8$, 82.1, 59.9, 55.6, 14.7 . $v_{\max } 1711,1566 \mathrm{~cm}^{-1}$. Mass spectrum (m/z) $245\left(\mathrm{M}^{+}, 100 \%\right), 230(23)$, 217 (29), 202 (42), 173 (15), 145 (12), 135 (40), 100 (9), 87 (13).

3-(2-Naphthyl)isoxazol-5(4H)-one (12d). Ethyl naphthoylacetate ${ }^{16}(0.5 \mathrm{~g}, 2.1 \mathrm{mmol})$ and hydroxylamine hydrochloride $(0.2 \mathrm{~g}, 6.3 \mathrm{mmol})$ were heated in water $(5 \mathrm{~mL})$ at $100{ }^{\circ} \mathrm{C}$ for $5 \mathrm{~min}$. 
Ethanol (8 mL) was added until homogeneity was achieved, and heating was then continued for $30 \mathrm{~min}$. The mixture was then chilled and the product was collected and washed with cold ethanol, giving pale pink needles of the title compound (0.33 g, 76\%), mp. 148-151 ${ }^{\circ} \mathrm{C}$. (Found: $\mathrm{M}^{+}$, 211.0634. $\mathrm{C}_{13} \mathrm{H}_{9} \mathrm{NO}_{2}$ requires $\mathrm{M}^{+}$, 211.0633). ${ }^{1} \mathrm{H}$ NMR $\delta$ 7.87-7.94, m, 5H; 7.54-7.64, m, 2H; 3.91, s, 2H. ${ }^{13} \mathrm{C}$ NMR $\delta$ 174.7, 163.0, 134.9, 132.7, 129.2, 128.7, 128.2, 128.0, 127.9, 127.3, 125.1, 121.9, 33.9. $\mathrm{v}_{\max } 1798,1560,1176 \mathrm{~cm}^{-1}$. Mass spectrum (m/z) $211\left(\mathrm{M}^{+}, 100 \%\right), 199(4)$, 185 (10), 169 (14), 153 (80), 143 (25), 127 (30), 111 (11), 97 (18), 83 (23), 73 (32), 57 (40), 43 (45).

\section{Reaction of 3-(2-Naphthyl)isoxazol-5(4H)-one 12d with ethyl propiolate}

3-(2-Naphthyl)isoxazol-5(4H)-one (0.33 g, $1.56 \mathrm{mmol})$, ethyl propiolate $(0.153 \mathrm{~g}, 1.56 \mathrm{mmol})$ and triethylamine $(0.16 \mathrm{~g}, 1.56 \mathrm{mmol})$ were reacted as above. The product, an orange oil $(0.422$ g), was purified by radial chromatography (10\% ethyl acetate/light petroleum) to give three fractions.

The first fraction contained (E)-5-(2-ethoxycarbonylethenyloxy)-3-(2-naphthyl)isoxazole 14d and its $(Z)$ isomer, as a colourless oil $(0.05 \mathrm{~g}, 9 \%)$. (Found: $\mathrm{M}^{+}$, 309.1006. $\mathrm{C}_{18} \mathrm{H}_{15} \mathrm{NO}_{4}$ requires $\mathrm{M}^{+}$, 309.1001). ${ }^{1} \mathrm{H}$ NMR $\delta$ 8.17, s, $1 \mathrm{H} ;$ 7.83-7.91, m, 4H; 7.51-7.57, m, 3H; 6.00, s, 1H; 5.91, d, $J=12.1 \mathrm{~Hz}, 1 \mathrm{H} ; 4.25$, q, $J=7.1 \mathrm{~Hz}, 2 \mathrm{H} ; 1.33$, t, $J=7.1 \mathrm{~Hz}, 3 \mathrm{H} .{ }^{13} \mathrm{C}$ NMR $\delta 169.6,165.5,164.4$, 153.8, 135.8, 134.2, 133.0, 128.8, 128.5, 127.8, 127.8, 127.2, 126.7, 126.6, 107.0, 80.0, 60.8, 14.2. $v_{\max }$ 1722, 1684, 1655, 1596, 1558, $1460 \mathrm{~cm}^{-1}$. Mass spectrum (m/z) $309\left(\mathrm{M}^{+}, 22 \%\right), 276$ (4), 242 (21), 194 (15), 183 (3), 166 (11), 155 (100), 139 (8), 127 (54), 115 (4), 77 (6).

The second fraction contained ethyl (E)-3-\{3-(2-naphthyl)-5-oxo-2,5-dihydroisoxazol-2yl p propenoate 13d which was obtained as a pale yellow solid (0.1 g, 21\%), mp. 150-152 ${ }^{\circ} \mathrm{C}$. (Found: $\mathrm{M}^{+}$, 309.0997. $\mathrm{C}_{18} \mathrm{H}_{15} \mathrm{NO}_{4}$ requires $\mathrm{M}^{+}$, 309.1001). ${ }^{1} \mathrm{H}$ NMR $\delta$ 7.99-8.02, $\mathrm{m}, 2 \mathrm{H}$; 7.917.95, m, 2; 7.61-7.65, m, 3H; 7.48-7.51, m, 1H; 5.91, d, $J=13.5 \mathrm{~Hz}, 1 \mathrm{H} ; 5.60, \mathrm{~s}, 1 \mathrm{H} ; 4.15$, q, $J=$ $7.1 \mathrm{~Hz}, 2 \mathrm{H}$; 1.23, t, $J=7.1 \mathrm{~Hz}$, 3H. ${ }^{13} \mathrm{C}$ NMR $\delta 166.8,166.3,160.8,134.5,133.3,132.7,129.8$, 129.1, 128.7, 128.6, 127.9, 127.7, 124.0, 122.2, 102.3, 91.5, 60.5, 14.2. v $v_{\max } 1771,1703,1636$, 1568, $12771182 \mathrm{~cm}^{-1}$. Mass spectrum (m/z) 309 (M+, 100\%), 281 (20), 264 (43), 236 (62), 219 (66), 192 (71), 179 (40), 165 (60), 152 (100), 139 (32), 127 (48), 115 (8), 69 (16).

The third fraction contained ethyl (Z)-3-\{3-(2-naphthyl)-5-oxo-2,5-dihydroisoxazol-2yl\}propenoate which was obtained as a yellow oil (0.04 g, 8\%). (Found: $\mathrm{M}^{+}, 309.1006$. $\mathrm{C}_{18} \mathrm{H}_{15} \mathrm{NO}_{4}$ requires $\mathrm{M}^{+}$, 309.1001). ${ }^{1} \mathrm{H}$ NMR $\delta$ 8.00-8.04, m, 2H; 7.91-7.96, m, 2H; 7.61-7.65, m, 2H; 7.50-7.55, m, 1H; 6.53, d, $J=9.5 \mathrm{~Hz}, 1 \mathrm{H}$; 5.55, s, $1 \mathrm{H}$; 5.32, d, $J=9.5 \mathrm{~Hz}, 1 \mathrm{H} ; 4.29$, q, $J$ $=7.1 \mathrm{~Hz}, 2 \mathrm{H} ; 1.35$, t $J=7.1 \mathrm{~Hz}, 3 \mathrm{H} .{ }^{13} \mathrm{C}$ NMR $\delta$ 167.0, 164.2, 162.0, 134.5, 133.2, 132.6, 129.8, 129.5, 129.1, 128.6, 128.5, 127.9, 127.6, 124.3, 105.0, 90.5, 61.1, 14.0. v $v_{\max } 1750,1732$, 1655, $1560 \mathrm{~cm}^{-1}$. Mass spectrum (m/z) 309 (M+, 96\%), 293 (13), 281 (19), 264 (50), 247 (20), 236 (68), 219 (66), 208 (63), 192 (70), 179 (39), 165 (52), 152 (100), 139 (26), 127 (50), 115 (8), 96 (5), 69 (16), 55 (6).

\section{Photolysis of 13d}

The $(E)$ isomer $(0.1 \mathrm{~g}, 0.32 \mathrm{mmol})$ was photolysed through pyrex at $300 \mathrm{~nm}$ in anhydrous 
acetone $(150 \mathrm{~mL})$ for $3 \mathrm{~h}$ as above. Radial chromatography (10\% ethyl acetate/light petroleum) gave four fractions.

The first fraction contained 2-acetylnaphthalene 17 (0.01 g, 18\%), m.p. $53{ }^{\circ} \mathrm{C}$ (lit. ${ }^{17} \mathrm{mp} .54{ }^{\circ} \mathrm{C}$ ), and had spectral data identical to that found in the literature. ${ }^{17} \mathrm{H}$ NMR $\delta 8.47$, s, $1 \mathrm{H} ; 7.87-8.06$, m, 4H; 7.53-7.64, m, 2H; 2.73, s, 3H. ${ }^{13} \mathrm{C}$ NMR. $\delta$ 197.8, 135.5, 134.4, 132.4, 130.0, 129.4, 128.34 128.3, 127.7, 126.6, 123.8, 26.6. $v_{\max } 1682 \mathrm{~cm}^{-1}$. Mass spectrum (m/z) $170\left(\mathrm{M}^{+}, 50 \%\right)$, 155 (100), 127 (59), 115 (5), 101 (6), 87 (4), 77 (7), 63 (8), 50 (5), 43 (17).

The second fraction contained ethyl 5-(2-naphthyl)pyrrole-3-carboxylate 15d as a white solid (0.02 g, 24\%), mp. 120-122 ${ }^{\circ} \mathrm{C}$. (Found: $\mathrm{M}^{+}$, 265.1103. $\mathrm{C}_{17} \mathrm{H}_{15} \mathrm{NO}_{2}$ requires $\mathrm{M}^{+}, 265.1103$ ). ${ }^{1} \mathrm{H}$ NMR $\delta$ 9.55, bs, $1 \mathrm{H}, \mathrm{NH}$; 8.00, s, $1 \mathrm{H} ; 7.82-7.89$, m, 3H; 7.69-7.72, m, 1H; 7.45-7.54, m, 2H; 7.01, dd, $J=2.5,3.9 \mathrm{~Hz}, 1 \mathrm{H} ; 6.67$, dd, $J=2.5,3.9 \mathrm{~Hz}, 1 \mathrm{H} ; 4.36$, q, $J=7.0 \mathrm{~Hz}, 2 \mathrm{H}$; 1.38 , t, $J=$ 7.0 Hz, 3H. ${ }^{13} \mathrm{C}$ NMR $\delta 161.3$, 136.6, 133.5, 132.7, 128.8, 128.7, 128.0, 127.7, 126.7, 126.1, 123.6, 123.1, 123,0, 116.8, 108.4, 60.5, 14.5 . v $v_{\max }$ 3324, $1690 \mathrm{~cm}^{-1}$. Mass spectrum (m/z) 265 ( $\left.\mathrm{M}^{+}, 60 \%\right), 219$ (100), 191 (50), 165 (23), 155 (9), 127 (5), 109 (3), 95 (8), 82 (9).

The third fraction $(0.022 \mathrm{~g})$ contained a mixture of the oxazole 18 and an unidentified acetone addition product.

Oxazole 18: ${ }^{1} \mathrm{H}$ NMR $\delta$ 8.08, s, $1 \mathrm{H} ; 7.81-7.91, \mathrm{~m}, 4 \mathrm{H} ; 7.71-7.75, \mathrm{~m}, 1 \mathrm{H} ; 7.48-7.56, \mathrm{~m}, 2 \mathrm{H} ; 4.33$, q, $J=7.1 \mathrm{~Hz}, 2 \mathrm{H}$; 3.78, s, 2H; 1.36, t, $J=7.1 \mathrm{~Hz}$, 3H. Mass spectrum (m/z) $281\left(\mathrm{M}^{+}, 3 \%\right), 262$ (5), 196 (100), 167 (20), 127 (24).

Unidentified adduct: ${ }^{1} \mathrm{H}$ n.m.r $\delta 10.18$, bd, $J=12.36 \mathrm{~Hz}, 1 \mathrm{H} ; 7.5-7.9$, m, 7H; 6.58, dd, $J=8.4$, $12.4 \mathrm{~Hz}, 1 \mathrm{H} ; 6.28$, d, $J=2.9 \mathrm{~Hz}, 1 \mathrm{H} ; 4.77$, d, $J=8.4 \mathrm{~Hz}, 1 \mathrm{H} ; 4.39$, q, $J=7.14 \mathrm{~Hz}, 2 \mathrm{H} ; 1.73$, s, $6 \mathrm{H} ; 1.4, \mathrm{t}, J=7.14 \mathrm{~Hz}$, 3H. Mass spectrum (m/z) 323(M+(CH3)2CO $\left.{ }^{+}, 93 \%\right), 277$ (100), 249 (29), 190 (28), 163 (21).

The fourth fraction contained ethyl 4-(2-naphthyl)pyrrole-3-carboxylate $\mathbf{1 6 d}$ as a pale yellow oil (0.015 g, 17\%). (Found: $\mathrm{M}^{+}, 265.1097 . \mathrm{C}_{17} \mathrm{H}_{15} \mathrm{NO}_{2}$ requires $\mathrm{M}^{+}$, 265.1103). ${ }^{1} \mathrm{H} \mathrm{NMR} \delta$ 9.06, bs, $1 \mathrm{H}, \mathrm{NH} ; 7.98-7.99$, m, 1H; 7.79-7.88, m, 3H; 7.63-7.67, m, 1H; 7.53, dd, $J=1.5,3 \mathrm{~Hz}, 1 \mathrm{H}$; 7.43-7.50, m, 2H; 7.04, dd, $J=1.5,3 \mathrm{~Hz}, 1 \mathrm{H} ; 4.33$, q, $J=7.1 \mathrm{~Hz}, 2 \mathrm{H} ; 1.38, \mathrm{t}, J=7.1 \mathrm{~Hz}, 3 \mathrm{H} .{ }^{13} \mathrm{C}$ NMR $\delta 164.9,133.5,133.0,132.4,129.1,128.8,127.7,126.6,125.8,124.4,123.0,121.7,118.3$, 107.2, 59.9, 14.5. $\mathrm{U}_{\max } 3311,1709,1561 \mathrm{~cm}^{-1}$. Mass spectrum (m/z) $265\left(\mathrm{M}^{+}, 100 \%\right), 252(12)$, 237 (28), 220 (64), 193 (32), 180 (3), 165 (30), 155 (24), 139 (4), 127 (13), 110 (28), 95 (5), 82 (16), 44 (49).

\section{Reaction of 3-methylisoxazol-5(4H)-one with ethyl propiolate}

3-Methylisoxazol-5(4H)-one 12e (0.8 g, $8 \mathrm{mmol})$, ethyl propiolate $(0.8 \mathrm{~g}, 8 \mathrm{mmol})$ and triethylamine ( $0.8 \mathrm{~g}, 8 \mathrm{mmol})$ were refluxed in dichloromethane $(15 \mathrm{~mL})$ for $30 \mathrm{~min}$. Workup as above gave a pale orange solid $(0.853 \mathrm{~g})$, which was purified by radial chromatography (10\% ethyl acetate/light petroleum), to give two main fractions.

The first fraction contained 5-(2-ethoxycarbonylethenyloxy)-3-methylisoxazole 14e as a colourless oil (0.07 g, 4\%). (Found: $\mathrm{M}^{+}, 197.0687 . \mathrm{C}_{9} \mathrm{H}_{11} \mathrm{NO}_{4}$ requires $\left.\mathrm{M}^{+}, 197.0688\right)$. ${ }^{1} \mathrm{H}$ NMR $\delta$ 7.75, d, $J=12 \mathrm{~Hz}, 1 \mathrm{H}$; 5.82, d, $J=12 \mathrm{~Hz}, 1 \mathrm{H}$; 5.41, s, $1 \mathrm{H} ; 4.13$, q, $J=7.1 \mathrm{~Hz}, 2 \mathrm{H}$; 2.23, s, 3H; 1.26, t, $J=7.1 \mathrm{~Hz}, 3 \mathrm{H} .{ }^{13} \mathrm{C}$ NMR $\delta 169.0,165.5,162.5,153.8,106.6,82.2,60.6,14.1,12.3 . v_{\max }$ 
1716, 1659, 1626, 1608, $1498 \mathrm{~cm}^{-1}$. Mass spectrum (m/z) $197\left(\mathrm{M}^{+}, 22 \%\right), 169$ (13), 152 (26), 128 (19), 112 (4), 99 (42), 82 (100), 71 (45), 54 (72), 42 (45).

The second fraction contained ethyl (E)-3-(3-methyl-5-oxo-2,5-dihydroisoxazol-2-yl) propenoate 13e which was obtained as a pale yellow solid (0.625 g, 39\%), mp. 87-90 ${ }^{\circ} \mathrm{C}$. (Found: $\mathrm{M}^{+}$, 197.0687. $\mathrm{C}_{9} \mathrm{H}_{11} \mathrm{NO}_{4}$ requires $\mathrm{M}^{+}$, 197.0688). ${ }^{1} \mathrm{H}$ NMR $\delta 7.49$, d, $J=13.2 \mathrm{~Hz}, 1 \mathrm{H} ; 5.72, \mathrm{~d}, J=$ $13.2 \mathrm{~Hz}, 1 \mathrm{H} ; 5.19$, q, $J=0.82 \mathrm{~Hz}, 1 \mathrm{H} ; 4.16$, q, $J=7.1 \mathrm{~Hz}, 2 \mathrm{H}$; 2.31, d, $J=0.82 \mathrm{~Hz}, 3 \mathrm{H} ; 1.24$, t, $J$ $=7.1 \mathrm{~Hz}, 3 \mathrm{H} .{ }^{13} \mathrm{C}$ NMR $\delta 166.7,166.4,156.3,130.2,100.6,91.0,60.4,14.1,11.5 . v_{\max } 1759$, $1698 \mathrm{~cm}^{-1}$. Mass spectrum (m/z) $197\left(\mathrm{M}^{+}, 74 \%\right), 180$ (2), 169 (9), 152 (100), 136 (8), 125 (34), 113 (14), 99 (7), 85 (56), 67 (24), 54 (13), 43 (16).

Flash vacuum pyrolysis of ethyl (E)-3-(3-methyl-5-oxo-2,5-dihydroisoxazol-2-yl)propenoate (13e)

Pyrolysis $\left(450{ }^{\circ} \mathrm{C}, 150{ }^{\circ} \mathrm{C}, 0.1 \mathrm{mmHg}\right)$ of $\mathbf{1 3 e}(0.05 \mathrm{~g}, 0.25 \mathrm{mmol})$ gave pale brown oil $(0.031 \mathrm{~g})$, which was purified by radial chromatography (10\% ethyl acetate/light petroleum) to give ethyl 5-methylpyrrole-3-carboxylate 15e as a white powder $(0.026 \mathrm{~g}, 66 \%)$, mp. $70{ }^{\circ} \mathrm{C}$ (lit. ${ }^{18} 70-71$ $\left.{ }^{\circ} \mathrm{C}\right) .{ }^{1} \mathrm{H}$ NMR $\delta$ 8.32, bs, $1 \mathrm{H}, \mathrm{NH} ; 7.28$, dd, $J=1.6,2.8 \mathrm{~Hz}, 1 \mathrm{H} ; 6.30$, bs, $1 \mathrm{H} ; 4.26$, q, $J=7.1 \mathrm{~Hz}$, 2H; 2.26, s, 3H; 1.35, t, $J=7.1 \mathrm{~Hz}, 3 \mathrm{H} .{ }^{13} \mathrm{C}$ NMR $\delta 166.1,128.9,122.3,116.2,107.2,61.7,14.3$, 12.6. umax 1676, 1645, $1560,1487 \mathrm{~cm}^{-1}$.

\section{Reaction of 3-methylisoxazol-5(4H)-one with ethyl but-2-ynoate}

3-Methylisoxazol-5(4H)-one (1.0 g, $10 \mathrm{mmol})$, ethyl 2-butynoate (1.13 g, $10 \mathrm{mmol})$ and triethylamine $(1.0 \mathrm{~g}, 10 \mathrm{mmol})$ were refluxed in ethanol $(15 \mathrm{~mL})$ at for $16 \mathrm{~h}$. The solvent was evaporated and the residue was redissolved in diethyl ether $(30 \mathrm{~mL})$ and washed with $1 \mathrm{M} \mathrm{HCl}$ (2 x $20 \mathrm{~mL})$. The organic layer was separated, dried $\left(\mathrm{Na}_{2} \mathrm{SO}_{4}\right)$, filtered and evaporated to give an orange oil (1.29 g), which was purified by radial chromatography (20\% ethyl acetate/light petroleum), to give two fractions.

The first fraction contained 5-(2-ethoxycarbonyl-1-methylethenyloxy)-3-methylisoxazole 14f as yellow oil (0.102 g, 5\%), (Found: $\mathrm{M}^{+}, 211.0842 . \mathrm{C}_{10} \mathrm{H}_{13} \mathrm{NO}_{4}$ requires $\mathrm{M}^{+}$, 211.0845). ${ }^{1} \mathrm{H} \mathrm{NMR} \delta$ 5.93, q, $J=1.37 \mathrm{~Hz}, 1 \mathrm{H}$; 5.73, q, $J=0.8 \mathrm{~Hz}, 1 \mathrm{H}$; 4.18, q, $J=7.1 \mathrm{~Hz}, 2 \mathrm{H}$; 2.48, d, $J=0.8 \mathrm{~Hz}$, 3H; 2.43, d, $J=1.37 \mathrm{~Hz}, 3 \mathrm{H} ; 1.26$, t, $J=7.1 \mathrm{~Hz}, 3 \mathrm{H} .{ }^{13} \mathrm{C}$ NMR $\delta 166.1,165.7,165.3,154.2,119.9$, 105.6, 60.6, 14.4, 14.2, 14.1. $v_{\max } 1713,1659,1622 \mathrm{~cm}^{-1}$. Mass spectrum (m/z) $211\left(\mathrm{M}^{+}, 1 \%\right)$, 196 (3), 165 (14), 150 (10), 127 (13), 113 (19), 99 (33), 88 (26), 82 (41), 69 (25), 55 (28), 43 (100).

The second fraction contained ethyl 3-(3-methyl-5-oxo-2,5-dihydroisoxazol-2-yl)but-2-enoate 13f, which was obtained as a yellow oil (0.87 g, 41\%). (Found: $\mathrm{M}^{+}, 211.0842 . \mathrm{C}_{10} \mathrm{H}_{13} \mathrm{NO}_{4}$ requires $\mathrm{M}^{+}$, 211.0845). ${ }^{1} \mathrm{H}$ NMR $\delta 5.71$, q, $J=0.96 \mathrm{~Hz}, 1 \mathrm{H} ; 5.14$, q, $J=0.82 \mathrm{~Hz}, 1 \mathrm{H} ; 4.15$, q, $J$ $=7.1 \mathrm{~Hz}, 2 \mathrm{H} ; 2.48, \mathrm{~d}, J=0.96 \mathrm{~Hz}, 3 \mathrm{H} ; 2.34$, d, $J=0.82 \mathrm{~Hz}, 3 \mathrm{H} ; 1.25$, t, $J=7.1 \mathrm{~Hz} .{ }^{13} \mathrm{C}$ NMR $\delta$ 167.8, 165.7, 158.8, 147.6, 107.6, 92.0, 60.3, 15.3, 14.7, 14.1. $v_{\max } 1750,1710,1626,1575 \mathrm{~cm}^{-1}$. Mass spectrum (m/z) $211\left(\mathrm{M}^{+}, 88 \%\right), 195$ (3), 182 (5), 166 (100), 150 (16), 139 (66), 122 (51), 110 (16), 99 (17), 82 (73), 67 (45), 54 (35), 39 (31).

Flash vacuum pyrolysis of $13 f$

Pyrolysis (450 $\left.{ }^{\circ} \mathrm{C}, 150{ }^{\circ} \mathrm{C}, 0.1 \mathrm{mmHg}\right)$ of $13 f$ (0.095 g, $0.45 \mathrm{mmol}$ ) gave ethyl 2,5- 
dimethylpyrrole-3-carboxlate $\mathbf{1 5 f}$ as colourless crystals (0.07 g, 93\%), mp. $116{ }^{\circ} \mathrm{C}$ (lit. ${ }^{19} 113{ }^{\circ} \mathrm{C}$ ). (Found: $\mathrm{M}^{+}$, 167.0947. $\mathrm{C}_{9} \mathrm{H}_{13} \mathrm{NO}_{2}$ requires $\mathrm{M}^{+}$, 167.0946). ${ }^{1} \mathrm{H}$ NMR $\delta$ 8.33, bs, $1 \mathrm{H}, \mathrm{NH} ; 6.18$, dq, $J=0.96,2.9 \mathrm{~Hz}, 1 \mathrm{H}$; 4.23, q, $J=7.1 \mathrm{~Hz}, 2 \mathrm{H} ; 2.46$, s, 3H; 2.17, d, $J=0.96 \mathrm{~Hz}, 3 \mathrm{H}$; 1.32, t, $J$ $=7.1 \mathrm{~Hz}, 3 \mathrm{H} .{ }^{13} \mathrm{C}$ NMR $\delta$ 165.6, 134.3, 125.6, 111.5, 107.3, 59.2, 14.5, 13.1, 12.5. $v_{\max } 1689$, 1437, 1224, $1087 \mathrm{~cm}^{-1}$. Mass spectrum (m/z) $167\left(\mathrm{M}^{+}, 68 \%\right), 138$ (100), 122 (23), 105 (3), 94 (8).

\section{Ethyl 3-(5-oxo-3-methyl-2,5-dihydroisoxazol-2-yl)-3-phenylpropenoate (13g)}

3-Methylisoxazol-5(4H)-one (1.0 g, 10.1mmol), ethyl phenylpropiolate (1.76 g, $10.1 \mathrm{mmol})$ and triethylamine (1.02 g, $10.1 \mathrm{mmol})$ were refluxed in ethanol $(30 \mathrm{~mL})$ for $16 \mathrm{~h}$. The product was purified by radial chromatography (20\% ethyl acetate/light petroleum), to give two fractions.

The first fraction contained unreacted ethyl phenylpropiolate $(0.777 \mathrm{~g})$.

The second fraction contained ethyl 3-(5-oxo-3-methyl-2,5-dihydroisoxazol-2-yl)-3phenylpropenoate 13g which was obtained as an orange oil (1.093 g, 71\%, based on unreacted starting material). (Found: $\mathrm{M}^{+}, 273.0989 . \mathrm{C}_{15} \mathrm{H}_{15} \mathrm{NO}_{4}$ requires $\left.\mathrm{M}^{+}, 273.1001\right) .{ }^{1} \mathrm{H} \mathrm{NMR} \delta 7.30-$ 7.38, m, 5H; 6.15, s, 1H; 5.09, q, $J=0.7 \mathrm{~Hz}, 1 \mathrm{H} ; 4.13$, q, $J=7.1 \mathrm{~Hz}, 2 \mathrm{H} ; 1.97$, d, $J=0.7 \mathrm{~Hz}$, 3H; 1.20, t, $J=7.1 \mathrm{~Hz}, 3 \mathrm{H} .{ }^{13} \mathrm{C}$ NMR $\delta 169.4,163.1,161.1,143.7,133.5,131.3,128.9,127.0,115.5$, 88.0, 60.9, 13.8, 12.4. umax 1758, 1718, 1623, 1576, 1448, 1368, $1282 \mathrm{~cm}^{-1}$. Mass spectrum (m/z) 273 (M+, 81\%), 228 (36), 200 (18), 175 (80), 156 (15), 147 (100), 131 (13), 116 (18), 103 (94), 91 (26), 69 (36).

\section{Flash vacuum pyrolysis of $\mathbf{1 3 g}$}

Pyrolysis $\left(450^{\circ} \mathrm{C}, 150^{\circ} \mathrm{C}, 0.01 \mathrm{mmHg}\right)$ of $\mathbf{1 3 g}(0.065 \mathrm{~g}, 0.23 \mathrm{mmol})$ gave pale brown oil (0.05 g), which was purified by radial chromatography (10\% ethyl acetate/light petroleum), to give two fractions.

The first fraction contained ethyl 5-methyl-2-phenylpyrrole-3-carboxylate 15g, which was obtained as a colourless oil (0.01 g, 19\%). (Found: $\mathrm{M}^{+}$, 229.1102. C14H15NO2 requires $\mathrm{M}^{+}$, 229.1103). ${ }^{1} \mathrm{H}$ NMR $\delta$ 8.13, bs, $1 \mathrm{H}, \mathrm{NH} ; 7.55-7.59$, $\mathrm{m}, 2 \mathrm{H} ; 7.29-7.41, \mathrm{~m}, 3 \mathrm{H} ; 6.40$, dq, $J=0.82$, $3 \mathrm{~Hz}, 1 \mathrm{H} ; 4.19$, q, $J=7.0 \mathrm{~Hz}, 2 \mathrm{H} ; 2.28$, d, $J=0.82 \mathrm{~Hz}, 3 \mathrm{H} ; 1.24$, t, $J=7.0 \mathrm{~Hz}, 3 \mathrm{H} .{ }^{13} \mathrm{C}$ NMR $\delta$ 165.0, 135.9, 132.3, 128.8, 128.0, 127.9, 127.6, 112.2, 109.6, 59.5, 14.3, 12.7. vmax $1672 \mathrm{~cm}^{-1}$. Mass spectrum (m/z) 229 (M+, 90\%), 201 (23), 184 (100), 170 (3), 156 (13), 141 (3), 128 (10), 104 (7), 77 (10).

The second fraction, colourless oil $(0.02 \mathrm{~g}, 38 \%)$ has not yet been identified. (Found: $\mathrm{M}^{+}$, 229.1092. $\mathrm{C}_{14} \mathrm{H}_{15} \mathrm{NO}_{2}$ requires $\mathrm{M}^{+}$, 229.1103). ${ }^{1} \mathrm{H}$ NMR $\delta$ 7.84-7.87, $\mathrm{m}, 2 \mathrm{H} ; 7.29-7.44, \mathrm{~m}, 3 \mathrm{H}$; 7.04, s, $1 \mathrm{H} ; 4.21$, q, $J=7.0 \mathrm{~Hz}, 2 \mathrm{H} ; 2.56$, s, 3H; 1.48, t, $J=7.0 \mathrm{~Hz}, 3 \mathrm{H}$; (OH unsighted). ${ }^{13} \mathrm{C}$ NMR $\delta 152.1,149.6,144.4,139.6,139.3,128.6,128.2,126.8,102.5,64.7,18.2,14.6 . v_{\max } 1473$, $1078 \mathrm{~cm}^{-1}$. Mass spectrum (m/z) 229 (M+, 100\%), 214 (6), 201 (56), 185 (17), 172 (29), 156 (5), 131 (9), 115 (6), 102 (10), 77 (9).

\section{Acknowledgements}


The authors are grateful for support of this project by the Australian Research Council. M.C. acknowledges the award of a Flinders University Research Scholarship.

\section{References and Notes}

1. Prager, R. H; Millan, D. S. Advances in Nitrogen Heterocycles. 2000, 4, 1.

2. $\quad$ Prager, R. H; Williams, C. M. Aust. J. Chem. 1996, 49, 1315.

3. Cox, M.; Heidarizadeh, F.; Prager, R.H. Aust. J. Chem. 2000, 53, 665.

4. Wender, P.A.; Cooper, C.B. Tetrahedron 1986, 42, 2985.

5. $\quad$ Marky, M.; Schmid, H.; Hauser, H.-J. Helv. Chim. Acta 1979, 62, 2129.

6. Edstrom, E.D.; Yuan, W. Tetrahedron Lett. 1991, 32, 323.

7. Barker, S.J.; Storr, R.C. J. Chem. Soc., Perkin Trans. 1 1990, 485.

8. Rees, C. W.; Storr, R. C. J. Chem. Soc. (C) 1969, 1478.

9. (a) Katritzky, A.R.; Rachwal, S.; Caster, K.C.; Mahni, F.; Law, K.W.; Rubio, O. J. Chem. Soc., Perkin Trans. 1 (1987), 781. (b) Katritzky, A. R.; Kuzmierkiewicz, W.; Rachwal, B.; Rachwal, S.; Thomson, J. J. Chem. Soc., Perkin Trans. 1 1987, 811.

10. Prager, R.H.; Williams, C.M. Heterocycles 1999, 51, 3013.

11. De Sarlo, F.; Fabbrini, L.; Renzi, G. Tetrahedron 1966, 22, 2989.

12. We thank Dr D.S. Millan for this observation.

13. Prager, R. H. ; Razzino, P. Aust. J. Chem. 1994, 47, 1673.

14. McCulloch, A. W. ; McInnes, A. G. Can. J. Chem. 1974, 52, 3569.

15. Clark, A.D.; Ha, U.T.; Prager, R.H.; Smith, J.A. Aust. J. Chem. 1999, 52, 1029.

16. Wierenga, W.; Skulnick, H. I. J. Org. Chem. 1979, 44, 310.

17. Pouchert, C. J.; Behnke, J. The Aldrich Library of ${ }^{13} \mathrm{C}$ and ${ }^{1} H$ FT NMR Spectra, $1^{\text {st }}$ Edn., Aldrich Chemical Company, 1993.

18. Padwa, A.; Gasdaska, J. R.; Tomas, M.; Turro, N. J.; Cha, Y.; Gould, I. R. J. Am. Chem. Soc. 1986, 108, 6739.

19. Alberola, A.; Ortega, A. G.; Sadaba, M. L.; Sanudo, C. Tetrahedron 1999, 55, 6555. 